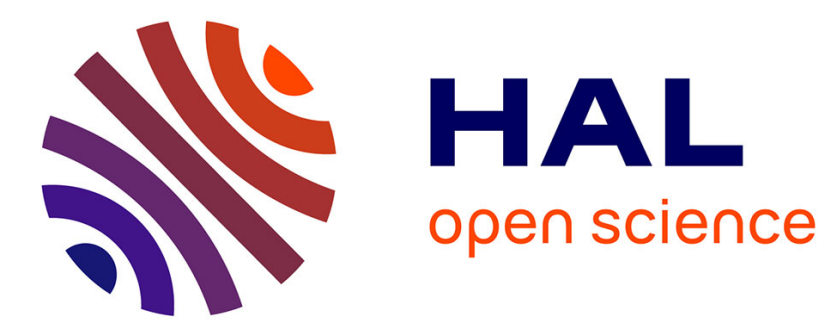

\title{
Volatility of elemental carbon
}

S. Jennings, C. O'Dowd, W. Cooke, P. Sheridan, H. Cachier

\section{- To cite this version:}

S. Jennings, C. O'Dowd, W. Cooke, P. Sheridan, H. Cachier. Volatility of elemental carbon. Geophysical Research Letters, 1994, 21 (16), pp.1719-1722. 10.1029/94GL01423 . hal-03587626

\section{HAL Id: hal-03587626 \\ https://hal.science/hal-03587626}

Submitted on 24 Feb 2022

HAL is a multi-disciplinary open access archive for the deposit and dissemination of scientific research documents, whether they are published or not. The documents may come from teaching and research institutions in France or abroad, or from public or private research centers.
L'archive ouverte pluridisciplinaire HAL, est destinée au dépôt et à la diffusion de documents scientifiques de niveau recherche, publiés ou non, émanant des établissements d'enseignement et de recherche français ou étrangers, des laboratoires publics ou privés. 


\title{
Volatility of elemental carbon
}

\author{
S.G. Jennings ${ }^{1}$, C.D. O'Dowd ${ }^{2}$, W.F. Cooke ${ }^{3}$, P.J. Sheridan ${ }^{4}$, and H.Cachier ${ }^{5}$
}

Abstract. A volatility technique whereby aerosol particles are heated to the relatively high temperature of $860{ }^{\circ} \mathrm{C}$ is used to infer the presence of elemental carbon in polluted air masses in the vicinity of the west coast of Ireland. The volume of elemental carbon for submicrometre sized particles contained in the aerosol is estimated from the fall off in number concentration at a critical onset temperature of about $730-735{ }^{\circ} \mathrm{C}$, as also obtained for laboratory carbon ink aerosol. The technique permits determination of the elemental carbon volume percentage of the total fine aerosol volume, and an estimation of the abundance of elemental carbon contained within the black carbon fraction of the atmospheric aerosol. Supplementary black carbon mass concentration measurements were obtained using a thermal method and an aethalometer absorption method. The work suggests that elemental carbon can be identified using the volatility technique and that it can yield sizesegregated information on the fraction of elemental carbon in atmospheric aerosol.

\section{Introduction}

Smoke aerosols are composed of two main fractions: the particulate organic component and a highly polymeric fraction referred to as the black carbon (or soot carbon) component. Atmospheric black carbon is the dark fraction of the carbonaceous aerosol where it represents 15 to $30 \%$ of the total carbon mass only (Wolff et al., 1982 and Cachier et al., 1990). The black carbon appears to have a low organic content as indicated by its relatively low $\mathrm{H} / \mathrm{C}$ ratio of the order of 0.4 (T.Kuhlbusch, personal communication, 1993). Within this black carbon fraction, pure elemental carbon (or graphitic carbon) is likely to form a significant fraction which up to now has not been evaluated.

The aerosol volatility work to date (including that of Pinnick et al (1987), Clarke et al (1987)), has permitted inference of at least three main atmospheric aerosol constituents: sulphuric acid, ammonium sulphate and sodium chloride. This letter describes the extension of the volatility technique to that of elemental carbon carbonaceous aerosols.

\footnotetext{
${ }^{1}$ Department of Experimental Physics, University College Galway, Ireland

${ }^{2}$ Department of Pure and Applied Physics, UMIST, Manchester, UK

${ }^{3}$ Environment Institute, CEC Joint Research Centre, Ispra, Italy

${ }^{4}$ Climate Monitoring and Diagnostics Laboratory, NOAA, Boulder, Colorado

${ }^{5}$ Centre des Faibles Radioactivites, Laboratoire mixte CNRSCEA, Gif sur Yvette, France.
}

Copyright 1994 by the American Geophysical Union.

Paper number 94GL01423

0094-8534/94/94GL-01423\$03.00

\section{Volatility Instrumentation}

The experimental arrangement is the same as that described by Jennings and O'Dowd (1990). The main core of the apparatus was that of a Particle Measuring System's (PMS) light scattering probe: Active Scattering Aerosol Spectrometer Probe (ASASP-X). The inlet to the probe consisted of a quartz tube, capable of being heated to the relatively high temperature of $860^{\circ} \mathrm{C}$.

Laboratory volatility measurements of carbon and carbonate aerosols.

The response of the volatility apparatus to polydisperse laboratory carbon aerosol was first examined. Polydispersions of carbon ink (Staedtler Mars 745) of concentration $1 \mathrm{ml} / 1$ in distilled water were generated using a De Vilbiss M40 glass nebulizer and then stored in a clean polythene bag before sampling. Measurements were made over 60 -minute temperature cycles, during which the ink carbon aerosol was heated to a temperature of $860{ }^{\circ} \mathrm{C}$ in approximately 3 minutes and then allowed to cool back close to ambient temperature for the remainder of the heating cycle. An example of the temperature-fractionation curves obtained for carbon ink aerosol for six heating cycles is shown in Figure 1. The temperature fractionation curves for carbon ink are for range 3 (0.09 - $0.195 \mu$ m diameter) and range $2(0.15-0.3 \mu \mathrm{m}$ diameter) of the particle sizing probe. The form of the fractionation curves were found to be largely independent of particle size. The refractory component of the aerosol evaporates at temperatures between about $730-735^{\circ} \mathrm{C}$ causing fairly rapid reduction in particle concentration beyond that temperature. The volatile properties of the following carbonate constituents: sodium carbonate, calcium carbonate and ammonium carbonate were also investigated in the laboratory and their temperature fractionation curves are shown in Figure 1.

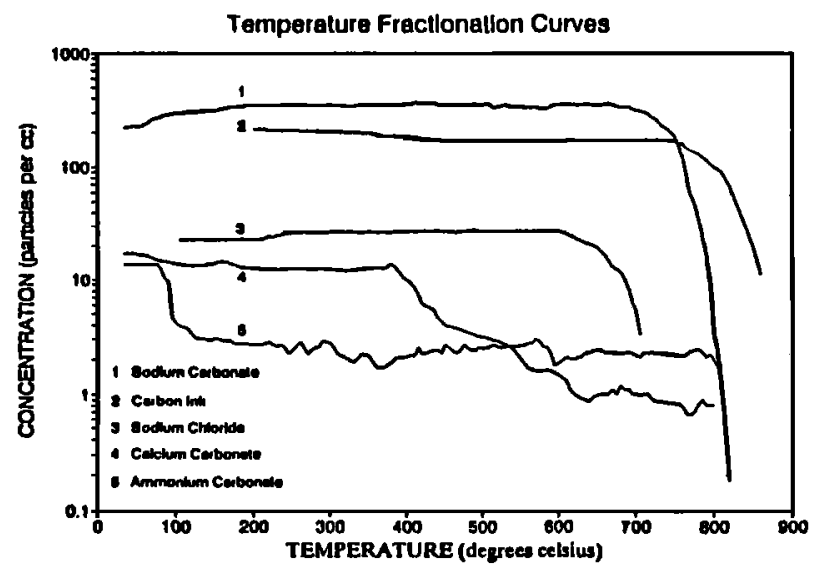

Figure 1 Laboratory aerosol temperature fractionation curves for sodium carbonate, carbon ink, sodium chloride, calcium carbonate and ammonium carbonate. 
Rapid fall off in particle concentration occurred for sodium carbonate, calcium carbonate and ammonium carbonate at temperatures of about $700^{\circ} \mathrm{C}, 380^{\circ} \mathrm{C}$ and $90^{\circ} \mathrm{C}$ respectively. The temperature-fractionation curve, obtained for sodium chloride, using the same volatility apparatus, is also included in Figure 1. Volatilization with resultant falloff in concentration begins at about $600{ }^{\circ} \mathrm{C}$. This allowed differentiation to be made between sodium chloride together with potential atmospheric aerosol carbonate constituents with that of elemental carbon. The laboratory measurements of carbon are used as a reference data set with which to compare ambient aerosol fractionation curves in order to infer the presence of elemental carbon as an atmospheric aerosol constituent mainly in the submicrometre range.

\section{Volatility of carbonaceous aerosol in the atmosphere}

Two sets of field measurements are presented in this study. The first set of measurements were made aboard a German research vessel, Friedrich Heinke off the west coast of Ireland, $\left(53^{\circ} .07 ' \mathrm{~N}, 9^{\circ} .39^{\prime} \mathrm{W}\right)$. The particle volatility equipment was placed above the bridge at a height of $18 \mathrm{~m}$ above the water level. The equipment was situated outside so that the aerosol was sampled as close as possible (in
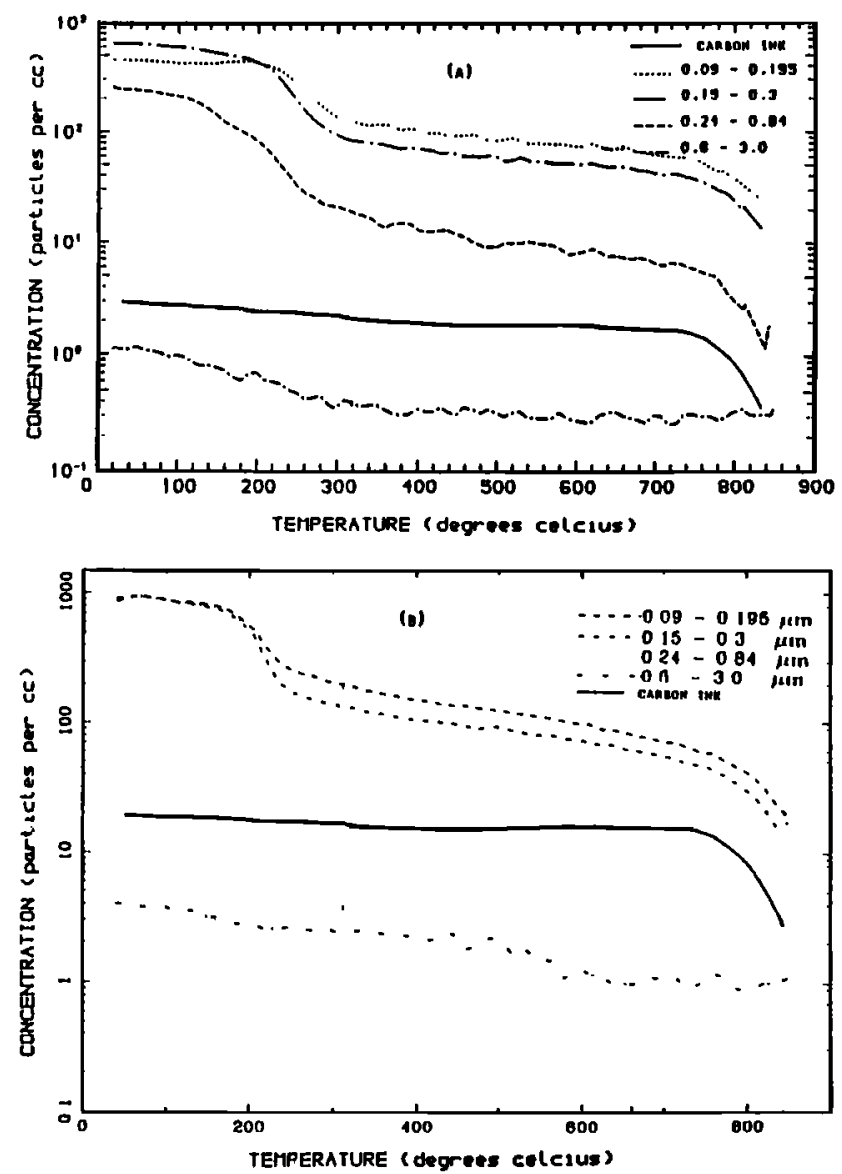

Figure 2(A) Temperature fractionation curve for aerosol at Killeany Bay, Aran Islands, off the west coast of Ireland, April 6,1989 for the temperature range from ambient to $860^{\circ} \mathrm{C}$.

(B) Temperature fractionation curve for aerosol at Mace Head atmospheric research station, on May 27, 1992, for the temperature range from ambient to $860^{\circ} \mathrm{C}$.

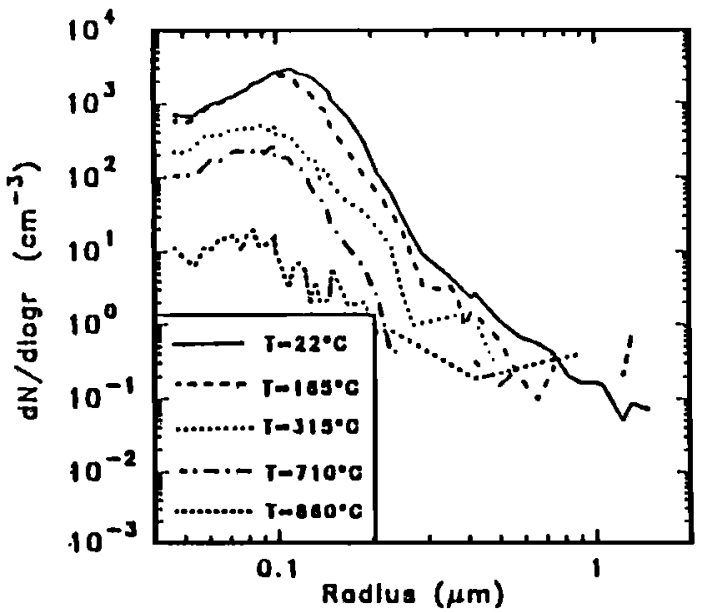

Figure 3 Aerosol number size distribution at Mace Head on 6 April 1989 for a range of temperatures.

order to minimize particle loss) to the inlet of the particle counter.

Back trajectories indicated that the air mass had recently traversed over the U.K. and Ireland transporting pollutants to the sampling location. An example of the aerosol volatility data taken is shown in Figure 2(A). Aerosol concentration per $c c$ in four particle size ranges is plotted versus temperature for the period April $61989 . \quad$ The ambient aerosol particle concentration levels remained relatively constant over the eight-hour period. The data has been averaged over the eight hourly cycles, so that a single temperature fractionation curve results for each particle range. The more rapid fall-off in particle concentration at around $730-740^{\circ} \mathrm{C}$ for the three lower size ranges resemble closely the laboratory thermal response data for carbon which is superimposed on the field data in Figure 2(A). The strong resemblance suggests that this fraction is composed predominately of elemental carbon aerosol. It is seen that the largest particle size fraction is unaffected at these high temperatures. Fluctuations in the number concentration of the larger sized particles is likely to be due to statistical noise, particular at the elevated temperatures (greater than about $400{ }^{\circ} \mathrm{C}$ ) due to the low concentrations encountered.

Volatility measurements made at the Mace Head atmospheric research station over the period 27-28 May 1992 are shown in Figure 2(B). The period was characterised by high pressure centred in north west Europe which brought continental polluted air masses from an easterly direction to the Mace Head site. The ambient aerosol concentration remained constant over a six hour period and an averaged temperature fractionation curve over the six cycles for each particle size interval is shown in Figure 2(B). A laboratory response curve for carbon ink aerosol is also superimposed on the data. The gradual continuous decrease in particle concentration between about 300 and $700{ }^{\circ} \mathrm{C}$ (seen also in Figure $2(\mathrm{~A})$ ) may be due to the volatilization of organic carbon and/or soot carbon (there is no clear cut distinction between the two components, Cachier et al (1989)). The observed sharp fall off at about $730^{\circ} \mathrm{C}$ for the two lowest size ranges we attribute to the volatilization of elemental carbon. The minor peaks appearing at around $430-500{ }^{\circ} \mathrm{C}$ may be due to (a) statistical fluctuations at those relatively low particle number 


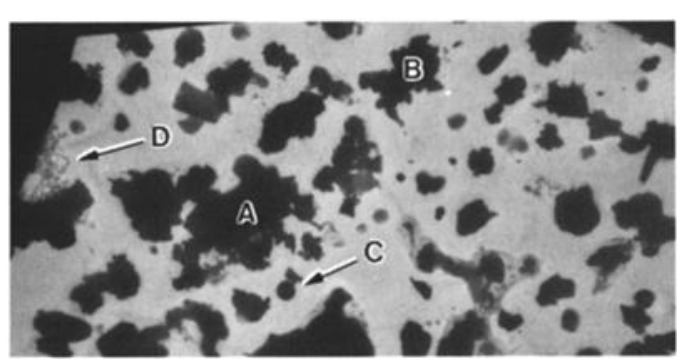

Figure 4 An electron microscope photomicrograph of aerosol particles collected at Mace Head, 27 May 1992. Particle A Large aggregate particle rich in $\mathrm{Na}$ and trace elements; very little carbon. Particle B - Carbon-rich aggregate with lots of crustal trace elements. Particle C - Small, spherical C-rich particle, probably a combustion sphere. Particle D Carbonaceous chain aggregate - mostly $\mathrm{C}$.

concentrations or (b) some charring of organic carbon and possibly of black carbon. Even if charring does occur with production of more black carbon or elemental carbon, the resultant increase in particle number concentration - of not more than a few particles $\mathrm{cm}^{-3}$ (Figure 2(B)) - will not affect the number concentration of the inferred elemental carbon by more than a few per cent. Figure 3 shows the change in particle number size distributions with temperature for the data of Figure 2(A). A significant reduction in particle number concentration, for particle radii up to about $0.2 \mu \mathrm{m}$, between temperatures $710^{\circ} \mathrm{C}$ and 860 ${ }^{\circ} \mathrm{C}$ is observed, which we attribute to the presence of elemental carbon. The volume and percentage of the total volume for the inferred elemental carbon is $0.28 \mu \mathrm{m}^{3} \mathrm{~cm}^{-3}$ and $4.2 \%$ respectively. The residual aerosol volume at 860 ${ }^{\circ} \mathrm{C}$ which is possibly of crustal origin was $0.4 \%$ of the total volume. The percentage volatilized between $315^{\circ} \mathrm{C}$ and $710{ }^{\circ} \mathrm{C}$ of the total volume was $7.1 \%$.

Supplementary measurements were available for the Mace Head data for the period 27 - 28 May 1992. The aerosol was collected on a formvar substrate with silicon monoxide coating and supported by transmission electron microscope (TEM) tabbed grids. Substrates were fixed to the three stages of a PIXE Corporation cascade impactor, - operating at $1 \mathrm{lpm}$ flow rate. A photomicrograph of a grid sample, shown in Figure 4, include agglomerations of sphenule particles. An X-ray spectrum of an aggregate particle (which is indicated by the letter $B$ in Figure 4) shows a considerable amount of carbon, considerably above the blank level, in Figure 5 indicating that carbon comprises a major mass fraction of that particle. The elevated potassium $\mathrm{K}^{+}$in Figure 5 is characteristic of combustion or biomass burning aerosols (Cachier et al (1991)). An inhouse fibrous glass $47 \mathrm{~mm}$ filter sampler was also used in

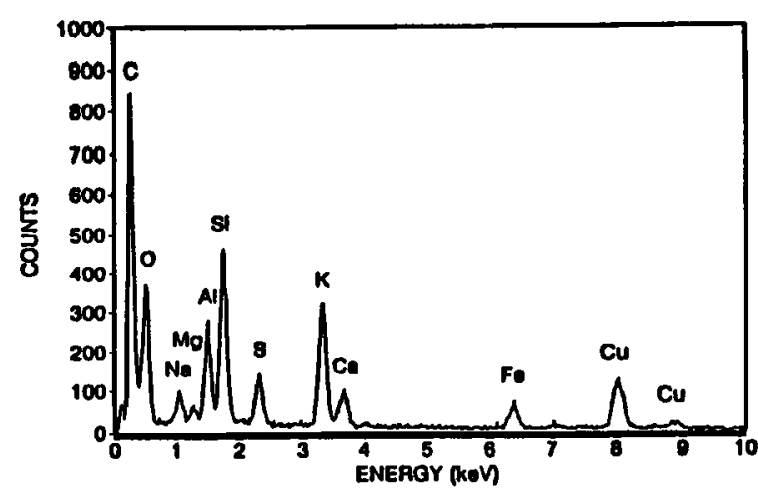

Figure 5 An X-ray spectrum of a $\mathrm{C}$ rich aggregate particle, identified as particle $B$ in Figure 4.

conjunction with a Bendix (Unico) 240 cyclone to collect ambient aerosol. A flow of $113 \mathrm{l} /$ minute through the cyclone yielded a particle diameter cut off size of $2.4 \mu \mathrm{m}$ (Chan and Lippman, 1977). Black carbon content $\left(\mu \mathrm{g} \mathrm{m}^{-3}\right)$ was determined using an analytical thermal method previously reported (Cachier et al, 1989).

An estimate of the mass due to elemental carbon was calculated from the differential number size distributions obtained by the ASASP-X probe, assuming a particular density. Whilst the density of elemental carbon is dependent on morphology and surface composition, a value of $2 \mathrm{~g} \mathrm{~cm}^{-3}$ is used here in line with values quoted in the literature. A summary of estimated mass concentration values for black carbon and elemental carbon using a range of techniques is shown in Table 1 for Mace Head aerosol data of May 27-28, 1992. The aethalometer (Hansen et al, 1984) values depend on the validity for use of a constant value $\left(19 \mathrm{~m}^{2} \mathrm{~g}^{-1}\right)$ for the attenuation cross-section, $\sigma$. However, Liousse et al (1993) find variations in $\sigma$ which are likely to depend on the source, age and type of mixing of the carbon aerosol. They obtain a $\sigma$ value of $12 \mathrm{~m}^{2} \mathrm{~g}^{-1}$ for suburban aerosol. A similar lowering in value of $\sigma$ for the Mace Head polluted episodes of May 27-28, 1992 would improve the degree of agreement between aethalometer inferred black carbon mass and that determined using the thermal method.

An estimate of the uncertainty in the ASASP-X data is obtained through comparison of its response characteristics for spherical particles of polystyrene latex (which closely approximates that of the manufacturer's calibration) with that of carbon. Despite a wide range of complex refractive index " $\mathrm{m}$ " values purported for carbon, a value of $\mathrm{m}=2$ $-1.0 \mathrm{i}$ based on a range of likely refractive index values is used. The theoretical responses' comparison shows that the ASASP-X will oversize carbon particles having radii less

Table 1. Comparison of Black Carbon and Elemental Carbon Mass Concentration ( $\mathrm{ng} \mathrm{m}^{-3}$ ) Values, using Different Methods, at the Mace Head Atmospheric Research Station.

\begin{tabular}{llll}
\hline Period & $\begin{array}{l}\text { Thermal method } \\
\text { (black carbon) }\end{array}$ & $\begin{array}{l}\text { Aethalometer average } \\
\text { value (black carbon) }\end{array}$ & $\begin{array}{l}\text { Inferred from volatility } \\
\text { data (elemental carbon) }\end{array}$ \\
\hline $\begin{array}{l}\text { May 27 1992 } \\
1021-2017\end{array}$ & $1037 \pm 105^{+}$ & $789 \pm 25^{\circ}$ & $594^{*}$ \\
$\begin{array}{l}\text { May 28 1992 } \\
\text { 0221-1019 }\end{array}$ & $1389 \pm 140$ & $624 \pm 4$ & 720 \\
\hline
\end{tabular}

0221-1019

+ Estimated precision in the range of $10 \%$ (Liousse et al., 1993). V Standard error based on some 40 individual measurements. *Inferred elemental carbon mass may be overestimated by up to a factor of 1.75 (see text). 
than $0.15 \mu \mathrm{m}$ (over ranges 2 and 3) by an average of $20.7 \%$, (an overestimation in mass by a factor of 1.75 ) if a calibration based on the polytyrene latex response is used. The particle sizing probe has a lower cut off diameter of $0.09 \mu \mathrm{m}$ which probably results in an underestimate of the number concentration of elemental carbon aerosol present. There may be some unvolatilised carbon remaining at the uppermost temperatures of the volatility apparatus. However, the volume of residue particles is only of the order of about $10 \%$ of the inferred carbon volume. Underestimation of particle mass may also occur due to the undersizing of the highly absorbing carbon particles greater than $0.15 \mu \mathrm{m}$ in radius through the use of the ASASP-X probe. The comparison between the inferred elemental carbon mass from the particle volatility measurements with the black carbon mass obtained using the thermal method gives a measure of the relative abundance of elemental carbon in the black carbon fraction of carbonaceous aerosols. A minimum percentage of about $30 \%$ of elemental carbon within the black carbon component is obtained, through using the upper limit correction to the inferred mass.

\section{Discussion}

A volatility technique is used to infer the presence and amount of elemental carbon in polluted air masses. It permits an in-situ, continuous and relatively rapid method of determining elemental carbon number and volumetric concentrations in the atmosphere. It should be pointed out however that the technique operates most effectively for relatively polluted air masses - possessing carbon mass concentration levels in excess of approximately $200 \mathrm{ng} \mathrm{m}^{-3}$. This is equivalent to a particle number concentration of 25 - 10 per $\mathrm{cm}^{3}$ for mean particle radii of $0.1-0.15 \mu \mathrm{m}$. This approximate threshold level is considered necessary to provide a sufficiently high signal to noise ratio, the noise being due to statistical fluctuations in low particle number concentrations, in the event of less polluted air masses.

A percentage of between about $2-4 \%$ of the estimated volume of elemental carbon to that of total aerosol volume in the $0.09-3.0 \mu \mathrm{m}$ diameter size range found in this work is in broad agreement with the finding of some other workers such as Stevens et al (1980) and Heintzenberg and Covert (1984). The morphological and X-ray spectral data provides supporting evidence for the presence of elemental carbon and black carbon in the sampled aerosol. In addition, the separate thermal measurement technique of Cachier et al (1989) on the bulk aerosol permitted comparison of black carbon content to be made with volatility inferred elemental carbon content.

Acknowledgements. The provision of air mass back trajectories for the Mace Head Atmospheric Research Station by Joyce Harris, CMDL, NOAA, Boulder, CO, USA is gratefully acknowledged. We also wish to thank Gunther Gassmann, chief scientist aboard the Friedrich Heincke and the crew, for ship time and their valuable help.

\section{References}

Cachier, H., M.-P. Bremond, and P. Buat-Menard, Determination of atmospheric soot carbon with a simple thermal method, Tellus, 41B, 379-390, 1989.
Cachier, H., M.P. Bremond, and P. Buat-Menard, Organic and black carbon aerosols in the remote marine atmosphere of the Northern Hemisphere, Proceedings of the International Conference on Global Atmospheric Chemistry (Beijing 1989), Newman and Kiang eds, Brookhaven National Laboratory, 249-261, 1990.

Cachier, H., J. Ducret, M.P. Bremond, V. Yoboue, J.P. Lacaux, A. Gaudichet, and J. Baudet, Biomass burning aerosols in a savanna region of the Ivory Coast. In: Global Biomass Buming, J.S. Levine (ed.), MIT Press, 174-180, 1991.

Chan, T., and M. Lippman, Particle collection efficiencies of air sampling cyclones: an empirical theory, Env. Sci. and Technol., 11, 377 - 382, 1977.

Clarke, A.D., N.C. Ahlquist, and D.S. Covert, The Pacific marine aerosol:evidence for natural acid sulfates, $J$. Geophys. Res., 92, 4179-4190, 1987.

Hansen, A.D.A., H. Rosen, and T. Novakov, The aethalometer - an instrument for the real-time measurement of optical absorption by aerosol particles, Sci. Total Environ., 36, 191-196, 1984.

Heintzenberg, J., and D.S. Covert, Size distribution of elemental carbon, sulphur and total mass in the radius range $10^{-6}$ to $10^{-4} \mathrm{~cm}$, Sci. Total Environ., 36, 289-297, 1984.

Jennings, S.G. and C.D. O'Dowd, Volatility of aerosol at Mace Head, on the west coast of Ireland, J. Geophys. Res., 95, 13,937-13,948, 1990.

Liousse, C., H. Cachier, and S.G. Jennings, Optical and thermal measurements of black carbon aerosol content in different environments: variation of the specific attenuation cross-section, sigma, (б), Atmos. Environ., 27A, 1203 $1212,1993$.

Pinnick,R.G., S.G.Jennings, and G. Fernandez, Volatility of aerosols in the arid Southwestern United States, J. Atmos. Sci. 44, 562-576, 1987.

Rosen, H., and A.D.A. Novakov, Optical transmission through aerosol deposits on diffusely reflective filters: a method for measuring the absorbing component of aerosol particles, Appl. Opt., 22, 1265-1267, 1983.

Stevens, R.K., T.G. Dzubay, R.W. Shaw Jr., W.A. McClenny, C.W. Lewis, and W.E. Wilson, Characterization of the aerosol in the Great Smoky mountains, Environ. Sci. Technol. 12, 1491-1498, 1980.

Wolff, G.T., P.J. Groblicki, S.H. Cadle, and R.J. Countess. Particulate carbon at various locations in the United States, In: Particulate Carbon: Atmospheric Life Cycle, Wolff G.T. and Klimisch, R.L., eds., Plenum Press, New York, 297315, 1982.

S.G. Jennings, Department of Experimental Physics, University College Galway, Ireland. (e-mail:phyjennings @bodkin.UCG.ie)

C.D. O'Dowd, Department of Pure and Applied Physics, UMIST, Manchester M60 1QD, England. (email:colin.o'dowd@mailhost.mcc.ac.uk)

W.F.Cooke, Environment Institute, T.P.460, Commission of the European Communities, Joint Research Centre, I-21020 Ispra (Varese), Italy (e-mail:william-cooke@ei.jrc.it)

P.J. Sheridan, Climate Monitoring and Diagnostics Laboratory, R/E/CGI, NOAA, 325 Broadway, Boulder, CO80303, USA.

H.Cachier, Centre des Faibles Radioactivites, CNRSCEA,91198-Gif sur Yvette, France (e-mail:cachier@eole.cfr. cnrs-gif.fr)

(Received July 29, 1993; revised December 10, 1993; accepted March 18, 1994.) 